\title{
Niabella soli sp. nov., isolated from soil from Jeju Island, Korea
}

\section{Correspondence \\ Soon-Wo Kwon \\ swkwon@rda.go.kr}

\author{
Hang-Yeon Weon, ${ }^{1}$ Byung-Yong Kim, ${ }^{2}$ Jae-Ho Joa, ${ }^{3}$ Soon-Wo Kwon, ${ }^{2}$ \\ Wan-Gyu $\mathrm{Kim}^{1}$ and Bon-Sung Koo ${ }^{2}$
}

\begin{abstract}
${ }^{1}$ Applied Microbiology Division, National Institute of Agricultural Science and Technology, Rural Development Administration, Suwon 441-707, Republic of Korea

${ }^{2}$ KACC - Korean Agricultural Culture Collection, Microbial Genetics Division, National Institute of Agricultural Biotechnology, Rural Development Administration, Suwon 441-707, Republic of Korea

${ }^{3}$ National Institute of Subtropical Agriculture, Rural Development Administration, Jeju 690-150, Republic of Korea
\end{abstract}

\begin{abstract}
A dark yellow-coloured bacterium, JS13-8 ${ }^{\top}$, was isolated from a soil sample from Jeju Island, Republic of Korea. The cells were aerobic, Gram-negative, non-motile, short rods $\left(0.5-0.7 \times 0.8-1.4 \mu \mathrm{m}\right.$ ). Growth occurred at $15-35{ }^{\circ} \mathrm{C}$ (optimally at $30{ }^{\circ} \mathrm{C}$ ), at $\mathrm{pH} 5.0-8.0$ (optimally at $\mathrm{pH} 6.0-7.0$ ) and at $0-1 \% \mathrm{NaCl}(\mathrm{w} / \mathrm{v})$. Flexirubin pigment was produced. $\mathrm{A}$ phylogenetic analysis based on 16S rRNA gene sequences revealed that strain $\mathrm{JS} 13-8^{\top}$ was closely related to Niabella aurantiaca KACC $11698^{\top}$ ( $95.0 \%$ sequence similarity). The major respiratory quinone system was MK-7 and the predominant cellular fatty acids were iso- $\mathrm{C}_{15: 0}$, iso- $\mathrm{C}_{15: 1} \mathrm{G}$, iso- $\mathrm{C}_{17: 0}$ 3-OH and summed feature 3. The DNA G+C content was $45 \mathrm{~mol} \%$. On the basis of the phylogenetic, physiological and chemotaxonomic data, strain JS13-8 ${ }^{\top}$ represents a novel species of the genus Niabella, for which the name Niabella soli sp. nov. is proposed. The type strain is strain JS13-8 ${ }^{\top}\left(=\right.$ KACC $12604^{\top}=$ DSM $\left.19437^{\top}\right)$.
\end{abstract}

The genus Niabella was proposed by Kim et al. (2007) for a bacterium isolated from soil. This genus was characterized as Gram-negative, aerobic, non-flagellated, flexirubinpigment-producing bacteria comprising short rods. Chemotaxonomically, the genus contains $\mathrm{MK}-7$ as the predominant isoprenoid quinone and iso- $\mathrm{C}_{15: 0}$, iso- $\mathrm{C}_{15: 1}$ $\mathrm{G}$, iso- $\mathrm{C}_{17: 0} 3-\mathrm{OH}$ and summed feature 3 as the major fatty acids. The type species of the genus is Niabella aurantiaca.

In the course of a study on the bacterial population of a soil sample from Jeju, Republic of Korea, we isolated a dark yellow bacterial strain. The soil sample was serially diluted with $0.85 \% \mathrm{NaCl}(\mathrm{w} / \mathrm{v})$ and the dilutions plated onto $\mathrm{R} 2 \mathrm{~A}$ agar (Difco). The strain was isolated after incubation for 4 days at $28{ }^{\circ} \mathrm{C}$.

Phenotypic characteristics, including Gram-staining, catalase activity, oxidase activity and hydrolysis of carboxymethylcellulose, casein, chitin, DNA, hypoxanthine, tyrosine, Tween 80, starch and xanthine, were performed using the methods of Smibert \& Krieg (1994). Cell morphology, motility and flagellation were investigated using phase-contrast and transmission electron microscopy with cells that had been negatively stained with $0.5 \%$

The GenBank/EMBL/DDBJ accession number for the $16 \mathrm{~S}$ rRNA gene sequence of strain $\mathrm{JS} 13-8^{\mathrm{T}}$ is EF592608. uranyl acetate. Growth under anaerobic conditions was tested in a GasPak (BBL) jar at $28{ }^{\circ} \mathrm{C}$ for 15 days on $\mathrm{R} 2 \mathrm{~A}$ medium. Growth at different temperatures and $\mathrm{pH}$ values was tested at between 5 and $45{ }^{\circ} \mathrm{C}$ (using increments of $5{ }^{\circ} \mathrm{C}$ ) and $\mathrm{pH} 4-10$ (using increments of $1 \mathrm{pH}$ unit). Salt tolerance was tested on R2A broth supplemented with 0,1 , 2, 3 and $5 \%(\mathrm{w} / \mathrm{v}) \mathrm{NaCl}$. Flexirubin pigment was detected from a colour shift after exposure to a $20 \%(w / v) \mathrm{KOH}$ solution (Reichenbach, 1992). Other biochemical tests were carried out by using API 20NE, API ID 32GN and API ZYM test kits according to the manufacturer's instructions (bioMérieux). Strain JS13 $-8^{\mathrm{T}}$ can grow on R2A, nutrient agar (Difco) and trypticase soy agar (Difco), but not on MacConkey agar (Difco). Phenotypic comparisons between strain JS13-8 ${ }^{\mathrm{T}}$ and N. aurantiaca KACC $11698^{\mathrm{T}}$ are shown in Table 1.

The presence of isoprenoid quinones was investigated using HPLC, as described previously (Groth et al., 1996). The cellular fatty acids of strain $\mathrm{JS} 13-8^{\mathrm{T}}$ were analysed using cells grown on R2A agar for 2 days. The cellular fatty acids were saponified, methylated and extracted according to the protocol of the Sherlock Microbial Identification System (MIDI, 1999). The G+C content of the chromosomal DNA was analysed as described by Mesbah et al. (1989) and was found to be $45 \mathrm{~mol} \%$. The major respiratory quinone system of strain JS13-8 ${ }^{\mathrm{T}}$ was MK-7. 
Table 1. Phenotypic comparisons between strain JS13-8 ${ }^{\top}$ and N. aurantiaca KACC $11698^{\top}$

Data for N. aurantiaca KACC $11698^{\mathrm{T}}$ were taken from Kim et al. (2007). + , Positive; - , negative. Fatty acids that account for $<0.5 \%$ of the total are not shown.

\begin{tabular}{|c|c|c|}
\hline Characteristic & $\mathrm{JS} 13-8^{\mathrm{T}}$ & 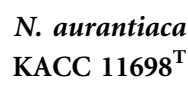 \\
\hline Catalase/oxidase & $+1+$ & $+1-$ \\
\hline Indole production & - & + \\
\hline Casein hydrolysis & - & + \\
\hline \multicolumn{3}{|l|}{ Assimilation of: } \\
\hline D-Mannitol & + & - \\
\hline Potassium gluconate & + & - \\
\hline D-Ribose & + & - \\
\hline \multicolumn{3}{|l|}{ Fatty acids $(\% \text { of total })^{*}$} \\
\hline anteiso- $\mathrm{C}_{15: 0}$ & 1.2 & 1.6 \\
\hline iso- $\mathrm{C}_{15: 0}$ & 29.2 & 33.7 \\
\hline iso- $\mathrm{C}_{15: 0} 3-\mathrm{OH}$ & 2.2 & 2.9 \\
\hline iso- $\mathrm{C}_{15: 1} \mathrm{G}$ & 18.4 & 22.3 \\
\hline $\mathrm{C}_{16: 0}$ & 6.8 & 3.5 \\
\hline $\mathrm{C}_{16: 0} 2-\mathrm{OH}$ & 1.3 & \\
\hline $\mathrm{C}_{16: 0} 3-\mathrm{OH}$ & 2.2 & 2.4 \\
\hline iso- $\mathrm{C}_{17: 0} 3-\mathrm{OH}$ & 11.8 & 15.5 \\
\hline $\mathrm{C}_{18: 0}$ & 3.8 & \\
\hline $\mathrm{C}_{18: 1} \omega 7 c$ & 1.5 & \\
\hline $\mathrm{C}_{18: 1} \omega 9 c$ & 1.0 & \\
\hline Summed feature $3^{*}$ & 11.1 & 10.6 \\
\hline Summed feature $5^{\star}$ & 3.4 & \\
\hline Unknown: ECL 13.565 & 1.1 & \\
\hline Unknown: ECL 16.582 & & 1.2 \\
\hline
\end{tabular}

${ }^{*}$ Summed feature 3 comprises iso- $\mathrm{C}_{15: 0} 2-\mathrm{OH}$ and/or $\mathrm{C}_{16: 1} \omega 7 c$; summed feature 5 comprises anteiso- $\mathrm{C}_{18: 0}$ and/or $\mathrm{C}_{18: 2} \omega 6,9 c$.

The major cellular fatty acids were iso- $\mathrm{C}_{15: 0}(29.2 \%)$, iso$\mathrm{C}_{15: 1} \mathrm{G}(18.4 \%)$, iso- $\mathrm{C}_{17: 0} 3-\mathrm{OH}(11.8 \%)$ and summed feature 3 (comprising iso- $\mathrm{C}_{15: 0} 2-\mathrm{OH}$ and/or $\mathrm{C}_{16: 1} \omega 7 c$, $11.1 \%$ ) (Table 1).

Genomic DNA extraction, PCR-mediated amplification of the $16 \mathrm{~S}$ rRNA gene and sequencing of PCR products were carried out as described by Kwon et al. (2003): a partial 16S rRNA gene sequence (1396 nt) for strain JS13-8 $8^{\mathrm{T}}$ was obtained. 16S rRNA gene sequences were aligned using CLUSTAL w (Thompson et al., 1994). A phylogenetic analysis was performed using MEGA, version 3.1 (Kumar et al., 2004). The phylogenetic tree was inferred using the neighbour-joining (Saitou \& Nei, 1987) and maximumparsimony (Fitch, 1971) methods. Bootstrap analysis based on 1000 replications was undertaken to test the robustness of the phylogenetic tree (Felsenstein, 1985). Isolate JS13-8 ${ }^{\mathrm{T}}$ showed the highest level of sequence similarity (95.0\%) with respect to $N$. aurantiaca KACC $11698^{\mathrm{T}}$ but showed low levels of sequence similarity $(<92 \%)$ with respect to other species included in this analysis. The phylogenetic tree also showed that strain JS13-8 $8^{\mathrm{T}}$ was grouped with $N$. aurantiaca KACC $11698^{\mathrm{T}}$ with $100 \%$ bootstrap support (Fig. 1). All branches of neighbour-joining tree were also present in the maximum-parsimony tree (data not shown).

Strain $\mathrm{JS} 13-8^{\mathrm{T}}$ can be clearly differentiated from $N$. aurantiaca on the basis of the novel strain's positive reaction for oxidase, its inability to produce indole or hydrolyse casein, its ability to assimilate D-mannitol, potassium gluconate and D-ribose and by the presence of some fatty acids such as $\mathrm{C}_{18: 0}(3.8 \%)$ and summed feature $5(3.4 \%)$.

On the basis of these results, strain JS13-8 ${ }^{\mathrm{T}}$ represents a novel species of the genus Niabella, for which the name Niabella soli sp. nov. is proposed.

\section{Description of Niabella soli sp. nov.}

Niabella soli (so'li. L. gen. n. soli of soil).

Colonies are dark yellow in colour, convex and round with clear margins. Cells are non-motile, Gram-negative, short rods that are $0.5-0.7 \mu \mathrm{m}$ in diameter and $0.8-1.4 \mu \mathrm{m}$ in length. Growth occurs at $15-35{ }^{\circ} \mathrm{C}$ (optimally at $30{ }^{\circ} \mathrm{C}$ ), at pH 5.0-8.0 (optimally at $\mathrm{pH} 6.0-7.0$ ) and with $0-1 \% \mathrm{NaCl}$ $(\mathrm{w} / \mathrm{v})$. Produces flexirubin pigment. Hydrolyses tyrosine and Tween 80. Does not hydrolyse casein, chitin, carboxymethylcellulose, DNA, hypoxanthine, starch or xanthine. Assimilates (in API 20NE and API ID 32GN strips) Dglucose, L-arabinose, D-mannose, $\mathrm{N}$-acetylglucosamine,

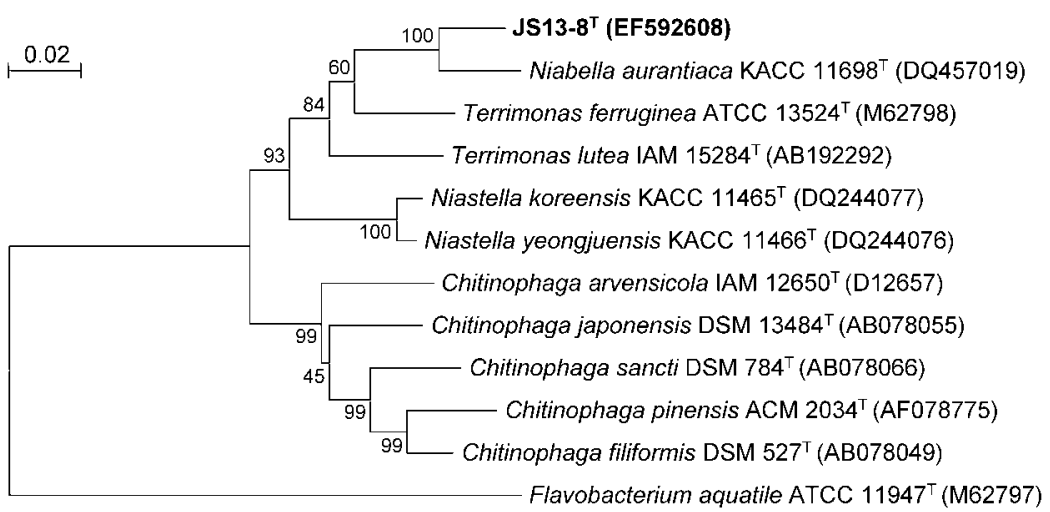

Fig. 1. Neighbour-joining phylogenetic tree, based on 16S rRNA gene sequences, showing the position of strain $\mathrm{JS} 13-8^{\top}$. Bootstrap values are shown as percentages of 1000 replicates. Bar, 2 substitutions per $100 \mathrm{nt}$. 
maltose, L-rhamnose, sucrose, salicin and melibiose. Does not assimilate capric acid, adipic acid, malic acid, trisodium citrate, phenylacetic acid, inositol, itaconic acid, suberic acid, sodium malonate, sodium acetate, lactic acid, Lalanine, potassium 5-ketogluconate, glycogen, 3-hydroxybenzoic acid, L-serine, L-fucose, D-sorbitol, propionic acid, valeric acid, L-histidine, potassium 2-ketogluconate, 3hydroxybutyric acid, 4-hydroxybenzoic acid or L-proline. Positive (in API 20NE and API ZYM strips) for aesculin hydrolysis, alkaline phosphatase, esterase (C4), esterase lipase (C8), leucine arylamidase, acid phosphatase, naphthol-AS-BI-phosphohydrolase, $\alpha$-galactosidase, $\beta$ galactosidase, $\beta$-glucuronidase, $\alpha$-glucosidase, $\beta$-glucosidase, $N$-acetyl- $\beta$-glucosaminidase, $\alpha$-mannosidase and $\alpha$-fucosidase, and negative for nitrate reduction, glucose fermentation, arginine dihydrolase, urease, gelatin hydrolysis, lipase (C14), valine arylamidase, cystine arylamidase, trypsin and $\alpha$-chymotrypsin. The predominant isoprenoid quinone is MK-7. The major cellular fatty acids are iso- $C_{15: 0}$, iso- $C_{15: 1}$ $\mathrm{G}$, iso- $\mathrm{C}_{17: 0} 3-\mathrm{OH}$ and summed feature 3. The DNA G $+\mathrm{C}$ content is $45 \mathrm{~mol} \%$.

The type strain, JS13-8 $8^{\mathrm{T}}\left(=\mathrm{KACC} 12604^{\mathrm{T}}=\mathrm{DSM} 19437^{\mathrm{T}}\right)$, was isolated from soil from Jeju Island, Republic of Korea.

\section{Acknowledgements}

This study was supported by the National Institute of Agricultural Biotechnology (grant no. 06-4-11-19-1), Rural Development Administration, Republic of Korea.

\section{References}

Felsenstein, J. (1985). Confidence limits on phylogenies: an approach using the bootstrap. Evolution 39, 783-791.
Fitch, W. M. (1971). Toward defining the course of evolution: minimum change for a specific tree topology. Syst Zool 20, 406-416.

Groth, I., Schumann, P., Weiss, N., Martin, K. \& Rainey, F. A. (1996). Agrococcus jenensis gen. nov., sp. nov., a new genus of actinomycetes with diaminobutyric acid in the cell wall. Int J Syst Bacteriol 46, 234-239.

Kim, B. Y., Weon, H.-Y., Yoo, S.-H., Hong, S.-B., Kwon, S.-W., Stackebrandt, E. \& Go, S.-J. (2007). Niabella aurantiaca gen. nov., sp. nov., isolated from a greenhouse soil in Korea. Int $J$ Syst Evol Microbiol 57, 538-541.

Kumar, S., Tamura, K. \& Nei, M. (2004). MEGA3: integrated software for molecular evolutionary genetics analysis and sequence alignment. Brief Bioinform 5, 150-163.

Kwon, S. W., Kim, J. S., Park, I. C., Yoon, S. H., Park, D. H., Lim, C. K. \& Go, S. J. (2003). Pseudomonas koreensis sp. nov., Pseudomonas umsongensis sp. nov. and Pseudomonas jinjuensis sp. nov., novel species from farm soils in Korea. Int J Syst Evol Microbiol 53, 21-27.

Mesbah, M., Premachandran, U. \& Whitman, W. B. (1989). Precise measurement of the $\mathrm{G}+\mathrm{C}$ content of deoxyribonucleic acid by highperformance liquid chromatography. Int J Syst Bacteriol 39, 159-167.

MIDI (1999). Sherlock microbial identification system, operating manual, version 3.0. Newark, DE: MIDI, Inc.

Reichenbach, H. (1992). The order Cytophagales. In The Prokaryotes. A Handbook on the Biology of Bacteria: Ecophysiology, Isolation, Identification, Applications, 2nd edn, pp. 3631-3675. Edited by A. Balows, H. G. Trüper, M. Dworkin, W. Harder \& K. H. Schleifer. New York: Springer.

Saitou, N. \& Nei, M. (1987). The neighbor-joining method: a new method for reconstructing phylogenetic trees. Mol Biol Evol 4, 406-425.

Smibert, R. M. \& Krieg, N. R. (1994). Phenotypic characterization. In Methods for General and Molecular Bacteriology, pp. 607-654. Edited by P. Gerhardt, R. G. E. Murray, W. A. Wood \& N. R. Krieg. Washington, DC: American Society for Microbiology.

Thompson, J. D., Higgins, D. G. \& Gibson, T. J. (1994). CLUSTAL W: improving the sensitivity of progressive multiple sequence alignment through sequence weighting, position-specific gap penalties and weight matrix choice. Nucleic Acids Res 22, 4673-4680. 